\title{
COMPARISON OF TECHNICAL METHODS OF SECURING CLOSED LANDFILLS IN THE CZECH REPUBLIC AND POLAND
}

\author{
Dana Adamcová \\ Faculty of AgriSciences, Mendel University in Brno
}

\begin{abstract}
Landfills and/or open dumpsites have been the common practice for municipal solid waste disposal all over the world. Landfilling is one of the oldest and still most frequently used waste disposal methods. The purpose of this work is to compare technical methods of securing landfills that are being closed in the Czech Republic and Poland. The Polish example of such is Słabomierz-Krzyżówka landfill site and the Czech example is Štěpánovice landfill. Closing landfills is a very important process in the aspect of environmental protection, which is of technological, legal and organizational nature. Reclamation of a landfill should be conducted in accordance with clearly presented time schedules that result from an administrative decision in a manner that protects the landfill against its adverse impact on the environment. These goals were achieved in both analysed landfills despite some differences in the closing process of both landfills.
\end{abstract}

Key words: landfill, technical reclamation, biological reclamation, protection

\section{INTRODUCTION}

The evolution of civilization, the increase in the population on our planet, the need to please society in various aspects, and an increase in the consumption of goods lead to a significant increase in the amount of waste produced (Laner, Crest, Scharff, Morris \& Barlaz, 2012; Ziyang, Luochun, Nanwen \& Youcai, 2015). An important group of waste are household waste and other municipal waste (e.g. household, bulky, office, catering, street waste) (Burlakovs et al., 2017). For example, in the United States $52.6 \%$ of municipal solid waste was discarded in landfills, in Brazil 59.1\%, in the Kingdom of Saudi Arabia $85 \%$, in Malaysia $94.5 \%$, in China $79 \%$, in Venezuela: sanitary landfills $32 \%$, controlled disposal $43 \%$ and non-controlled disposals or open dumps $24 \%$, in Mexico: sanitary landfills $65 \%$, in uncontrolled and open dumps 30\%, in Thailand $27 \%$ (Vaverková, 2019). In the second half of the 1990s, the annual volume of waste production ranged between $300-800 \mathrm{~kg}$ per capita in developed countries and less than $200 \mathrm{~kg}$ per capita in other countries (Ercolano, Gaeta, Ghinoi \& Silvestri, 2018). In Poland, around $300 \mathrm{~kg}$ of waste is produced on average per year, while in the Czech Republic the number of kilograms per person is slightly higher than in Poland (Eurostat, 2016). In the European Union on average the majority of collected waste goes to landfills. Although, in accordance with the recommendations of the Community directives, programmes to reduce the amount of waste deposited have been adopted, while focusing on the implementation of various forms of recovery of raw materials and energy from waste. Small, depleted landfills or the ones that do not meet technical facili- 
ties standards and environmental requirements are being closed.

Landfilling is one of the oldest and still most frequently used waste disposal methods (Pietzsch, Ribeiro \& Medeiros, 2017; Ishimura \& Takeuchi, 2019). This is due to the low operating costs of landfills in comparison to other methods of disposal (Jovanov, Vujić \& Vujić, 2018; Abad, Avila, Vicent \& Font, 2019). From the beginning of the 1980s in Poland, waste has been deposited in depressions of the ground and could not be used for other purposes. No insulation or degassing system were used (Koda \& Osiński, 2017). Currently, landfills should meet legal requirements as a consequence of adapting EU conditions (Decision 1386/2013/EU; Peri, Ferrante, La Gennusa, Pianello \& Rizzo, 2019). Waste landfills must fulfil operational and technical conditions. They should be properly located and, simultaneously, hydrogeological and geotechnical requirements should be considered (Peri, Ferrante, La Gennusa, Pianello \& Rizzo, 2019). In the case of old depleted landfills that are being closed, it is often necessary to carry out tests determining the hydrogeological and geotechnical conditions and data on deposited waste for the purpose of preparing reclamation projects (Koda, 2009; Manczarski \& Lewicki, 2012).

The purpose of this work is to compare technical methods of securing landfills that are being closed in the Czech Republic and Poland. The Polish example of such is Słabomierz-Krzyżówka landfill site in Radziejowice municipality. The Czech Republic example is Štěpánovice landfill in the Pilsen Region. The preparation of closure and reclamation projects for these landfills has taken into account existing formal and legal regulations in the country and EU directives. In EU countries, general design brief for closing and reclamation of waste landfills is contained in Council Directive 1999/31/EC. In Poland, reclamation of waste landfills is being carried out in accordance with the 2013 Regulation of the Minister of the Environment. In the Czech Republic, landfill reclamation is carried out in accordance with the ČSN 838035 regulation from 1996. The goal of the work is comparison of technical methods of securing closed landfills in the Czech Republic and Poland.

\section{COMPARISON OF SECURITY FEATURES OF CLOSED LANDFILLS BASED ON SELECTED LANDFILLS IN POLAND AND THE CZECH REPUBLIC}

Two specific landfills were selected to compare the security features of closed landfills - Polish Słabomierz-Krzyżówka landfill and in the Czech Štěpánovice landfill. The Słabomierz-Krzyżówka landfill is located on the grounds of the village of Krzyżówka (near the village of Stabomierz border), in the place of the old excavation after sand pit. Administratively, the area belongs to the Radziejowice municipality, Żyrardów Poviat, Mazowieckie Voivodship. GPS coordinates of Krzyżówka - 51 ${ }^{\circ} 59$ '51.108”N, $20^{\circ} 28^{\prime} 58.122$ '” (Fig. 1).

The area is located about $2 \mathrm{~km}$ from the borders of Mszczonów and about $6 \mathrm{~km}$ from Żyrardów. The Central Rail Line (Centralna Magistrala Kolejowa CMK) runs along the west side of the landfill, while national road 50 (Mińsk Mazowiecki - Sochaczew) runs from the east. The southern and northern sides of the landfill border with unused grassy green areas with clusters of trees and shrubs that occur on the border of the landfill and are no longer actively used.

Together with the facilities within the current development, the landfill covers an area of 14.21 ha and the area for waste storage is 8.7 ha.

The Słabomierz-Krzyżówka landfill has been in use since 1970. It was formed at a location of a deep gravel and sand pit that was exploited for the needs of the Central Rail Line that was being built at that time. In the years 1970-1992, the municipal and industrial waste from the area and the vicinity of Żyrardów was stored at the landfill. Since 1992, the landfill management company has been Przedsiębiorstwo Gospodarki Komunalnej Żyrardów Sp. z o.o. Waste that was deposited in the landfill was subjected to initial segregation.

The landfill is equipped with a biogas recovery installation, the purpose of which is conversion into electricity. The installation includes 68 wells for obtaining biogas, as well as two collectors supplying gas to the collecting station next to the gen- 


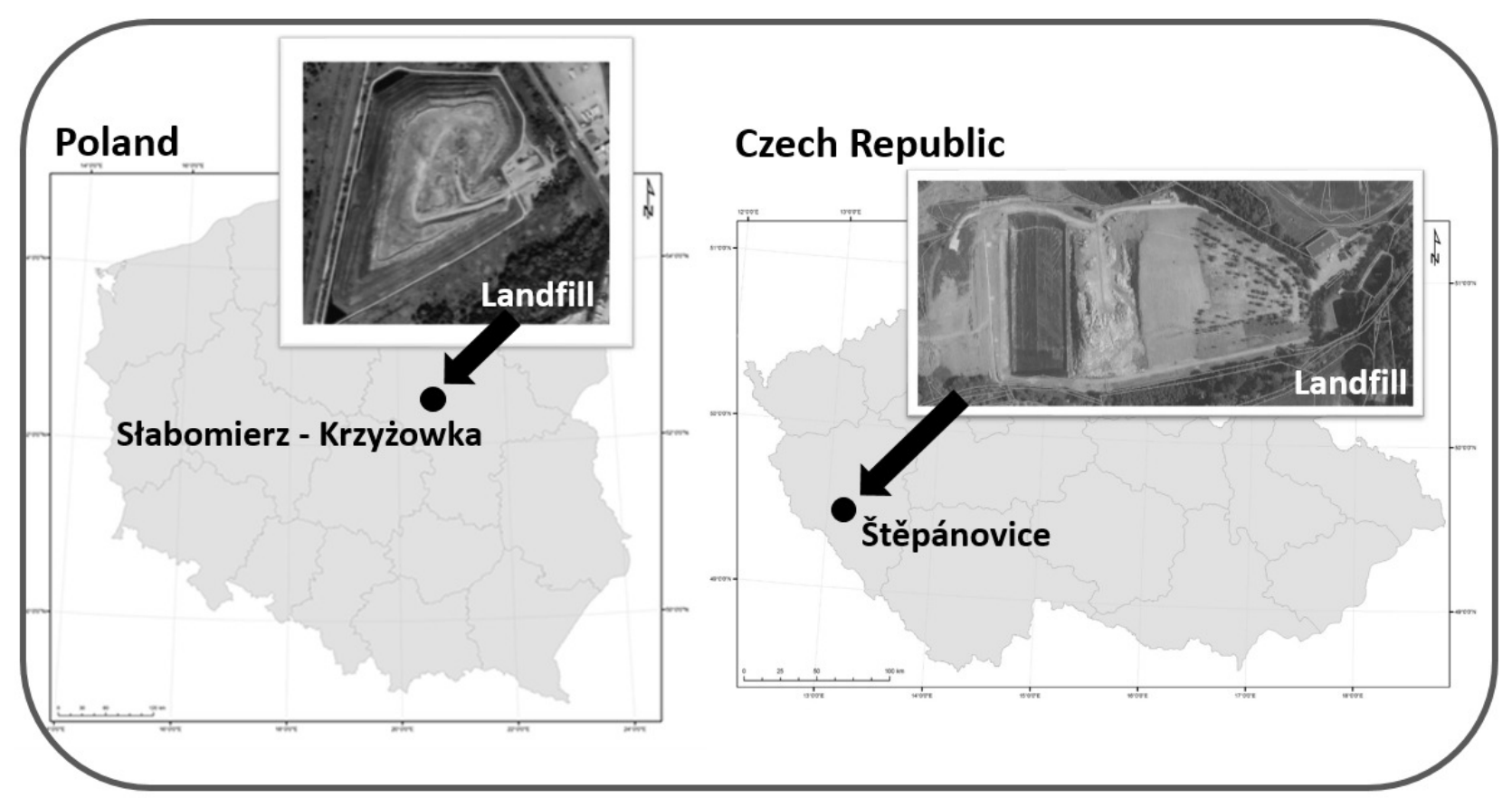

Fig. 1. Locations of landfills

erator located in the backyard of the landfill. The wellbores for gas wells were completed in 2002 and 2007. They were 6-11-meter deep. Thanks to biogas recovery, it is possible to produce $2 \mathrm{M} \mathrm{kWh}$ of electricity.

From the side of the national road 50 , the area is separated by a 15 -meter wide green belt. The fence of the landfill site was created from concrete slabs and has three gates.

The installed monitoring network allows constant monitoring of the environmental impact of the landfill. The layout of the monitoring network for the Słabomierz-Krzyżówka landfill consists of observation points: (1) four piezometers controlling the quality of groundwater; (2) diurnal measurement of precipitation; (3) four research points on surface watercourses; (4) ongoing analysis of the composition and emission of landfill gas at the place of the collecting station; (4) two leachate collection points; (5) slope stability analysis and landfill surface settlement measurements (Górecka \& Koda, 2010). The landfill ended waste collection works on 30 June 2019 , and currently does only reclamation works.

\section{SŁABOMIERZ-KRZYŻÓWKA AS AN EXAMPLE OF A CLOSED LANDFILL IN POLAND - CHARACTERISTICS AND DESCRIPTION OF SECURITY FEATURES}

In order to secure the Słabomierz-Krzyżówka landfill, the following elements were constructed as part of technical reclamation: (1) a vertical anti-filtration barrier with a technological route around the landfill; (2) a system for collecting and managing leachate from the landfill; (3) shaping the body of the landfill and modernizing the entry roads; (4) gradual introduction of vegetation on the surface of closed parts of the landfill.

In 2012, as part of the first element mentioned above, a vertical anti-filtration barrier was created around the entire landfill, which was connected to a continuous layer of impermeable soils located in its base. It created a part of a tight "bathtub" under the landfill, which protects against movement leachate to adjacent areas. The design length of the barrier is $1,440 \mathrm{~m}$, the enclosed area inside the barrier -11.1 ha, average depth $-7 \mathrm{~m}$ and thickness $0.6 \mathrm{~m}$, 
side area about $10,000 \mathrm{~m}^{2}$. Material filtration coefficient (bentonite) of the barrier is $k<10^{-9} \mathrm{~m} \cdot \mathrm{s}^{-1}$.

Drainage in the north-western slope consists of three sections. The lengths of individual sections are 79.0, 71.2 and $42.0 \mathrm{~m}$. The drainage lines run with a $0.2 \%$ drop. Control wells to which finger-jointed drainages have already been connected, have been designed on the drainages. The ordinate of connections as well as the arrangement of the well were adapted to the actual location of existing finger drainage. The drainage was made of perforated pipes (internal pipe diameter $160 \mathrm{~mm}$ ) in a gravel filtration backfill. The inspection chambers were made of elements such as: concrete rings (diameter $1,000 \mathrm{~mm}$ ), concrete bottom on the gravel deck (thickness $20 \mathrm{~cm}$ ) and solid concrete cover.

The slopes of the landfill body were formed with a slope of $1: 2$ to the level of the crown of the landfill on the ordinate $172.00-173.00 \mathrm{~m}$ a.s.l. along with technological, 4-meter wide, shelves. To prevent washing and erosion of the outer edges of the slopes, technological shelves were used, which were formed with a 3\% transverse slope towards the landfill. The stability is ensured, the stability factor for all slopes is greater than 1.3.

Due to high level of the steepness of slopes, they were shaped using the method involving rollers of compacted clay. These rollers create a type of protection against the waste stored below being moved by the wind. There is no need for a drainage layer in the layer covering the surface of the landfill, because the new slopes of the landfill have a relatively large slope. Protective rollers are about 2-meter high. After the completion of ground works and profiling the slope, the cohesive soil-forming layer or compost was successively laid and sown with a grass mixture. Figure 2 shows a scheme for forming landfill slopes.
Waste that fills the main part of the landfill was formed in 1.5-2.0-meter thick layers. Density of each of them was increased with the use of a compactor. Compaction level was monitored using a static screw-in probe. The number of rides depended on the type of deposited material. During the creation of the final surface of the slopes and shelves, as well as the area on the crown of the landfill, the insulation layer was formed as a covering of the landfill (Górecka \& Koda, 2010).

The capping of the surface of the dump was made by forming the following layers: (1) insulation layer (cohesive soil or optionally soil with bentonite); (2) drainage layer (sand); (3) soil-forming layer (humus).

The main purpose of covering the landfill (insulation) was to reduce the infiltration of melt and rainwater into the landfill. The use of such a system in the post-mining phase significantly reduced the capacity of water migration to the body of the landfill. Thanks to that the amount of leachate generated as a result of infiltration of rainwater through the stored waste was reduced. Biogases at the Słabomierz-Krzyżówka landfill are captured as a part of the degassing system, and then subject to combustion in power generating devices.

The layer that acts as an insulation surface of the landfill should be formed of a mineral material with special properties (e.g. clay) or with an admixture of a substance improving insulation properties (e.g. bentonite). According to legal requirements, in Poland it is not required to cover the surface of a municipal landfill with a geomembrane. In the process of covering the landfill, a soil-forming layer is laid on the surface, which contains a top humus layer (e.g. compost) and a drainage layer for the collection of rainwater free of pollution. Medium, usually $0.15-0.20$-meter thick, sand is used to make the drainage layer. The layer is

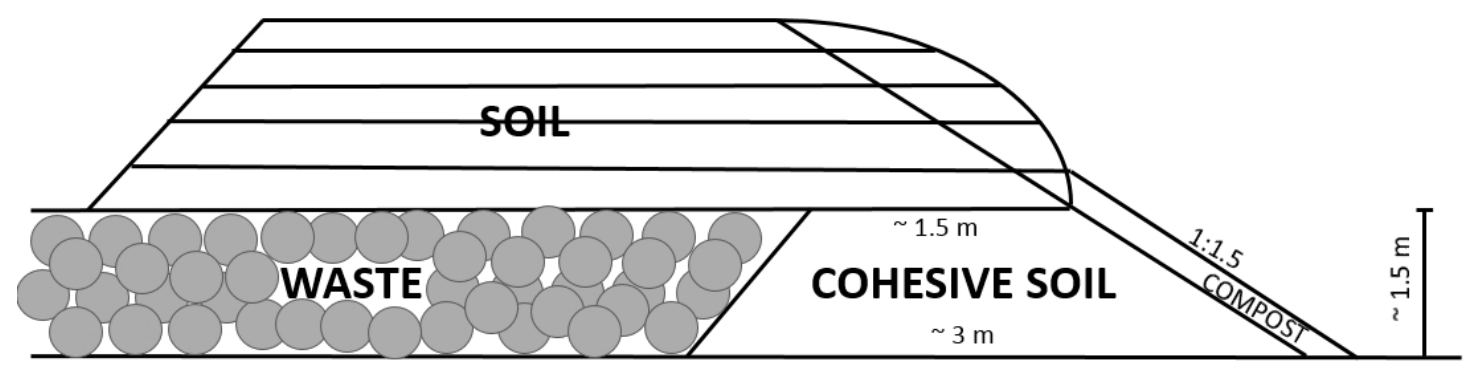

Fig. 2. Scheme for forming landfill slopes 
intended to retain water in the zone at the root vegetation, as well as excess to drain melt and rainwater to the retention tank. The top layer of the cover (reclamation) is formed from mineral soil improved by the addition of compost. The soil-forming layer built in this way is a substrate for vegetation and creates protection of the landfill slopes against erosion. The task of the thickness of the outer reclamation layer is to facilitate the growth and long-term existence of the plant cover (Koda, Pachuta \& Osiński, 2013).

The task of biological reclamation is to create a plant cover on the surface of the landfill. Planting vegetation creates significant economic and technical problems. It is expensive to plant shrubs and trees and generating the covering does not always bring the expected end result. Therefore, prior to planting greening, it is recommended to accurately stockcount and check the condition of indigenous vegetation, naturally growing in a given reclamation area, in order to be able to integrate it into the designed target land use (Górecka \& Koda, 2010).

Vegetation that can be used for biological reclamation of a landfill should be characterized by: (1) significant resistance to eutrophication; (2) possessing sanitation properties; (3) forming a thick plant cover with long growing time; (4) having low care requirements; (5) creating a spacious and strong root system that will stabilize the ground (slope of the landfill); (6) leaves and shoots of considerable size, thanks to which it will be possible to protect the ground against wind and reduce erosive activity after heavy rains. The prolonged vegetation period and significant development of plant cover reduce surface runoff from the landfill, which can lead to its total exclusion during light rainfall, as well as to a smaller infiltration of irrigation water. When selecting individual plant species for the purposes of landfill reclamation, observations of the currently occurring vegetation were used (Koda et al., 2013).

Planting vegetation in a landfill should be aimed for variable and multi-species plant cover. Planting monocultural plants is not recommended because it may be destroyed due to periodic lack of water or excess water. It is also necessary to choose plant varieties appropriately for the type of habitat (e.g. with high availability of sun, humidity, water) and function. Biological reclamation should be carried out in a short time, but it should be relatively extended to adapt it to the pace of other reclamation treatments in the best possible way. The planting and sowing process should be carried out simultaneously with the other works.

During reclamation works it is not recommended to conduct final plant management. However, plants should be placed in clusters to observe which types of them meet their target expectations. It also guarantees a way of achieving your own substance for sowing and planting, thanks to which a reduction of costs can be achieved, and the planted vegetation will be of various age. An exception from this is sowing grass mixtures on the slopes of the landfill, immediately after their construction, aimed at protection against erosion. By increasing the thickness of the reclamation layer and expanding the part of the already closed at the height of $175 \mathrm{~m}$ a.s.l. landfill, the area (the volume for temporary water storage at the crown of the landfill) of the analysed landfill increased. It has a positive effect on the efficiency of the leachate management process and will reduce the volume of exported leachate.

\section{ŠTĚPÁNOVICE AS AN EXAMPLE OF A CLOSED LANDFILL IN THE CZECH REPUBLIC - CHARACTERISTICS AND DESCRIPTION OF SECURITY DEVICES}

The analysed landfill site is located in the Pilsen Region, in the western part of the Czech Republic, about $1 \mathrm{~km}$ north from the Štěpánovice municipality and $1 \mathrm{~km}$ south from the Dehtín municipality. GPS coordinates $-49^{\circ} 26^{\prime} 15.934^{\prime \prime} \mathrm{N}, 13^{\circ} 16^{\prime} 55.352^{\prime \prime} \mathrm{E}$ (Fig. 3).

The landfill has three sections: A, B and C. The total area of parts A and B of the landfill is $289,000 \mathrm{~m}^{3}$. The planned operating period of the facility is 2024 .

Up to $37.5 \mathrm{t}$ of waste are placed in a landfill daily. Treated waste includes: solid municipal waste, inert waste and material used to cover the landfill. Waste may contain scraps of paper, plastics, metals, packaging, used tires, textiles, building materials, etc.

The landfill is located on an impermeable natural clay layer. Lower and lateral slopes may differ, however, they usually contain several protective layers, such as: compact clay layer $(100 \mathrm{~cm})$, geosynthetic membranes, gravel $(50 \mathrm{~cm})$, protective and non-woven geotextile. 


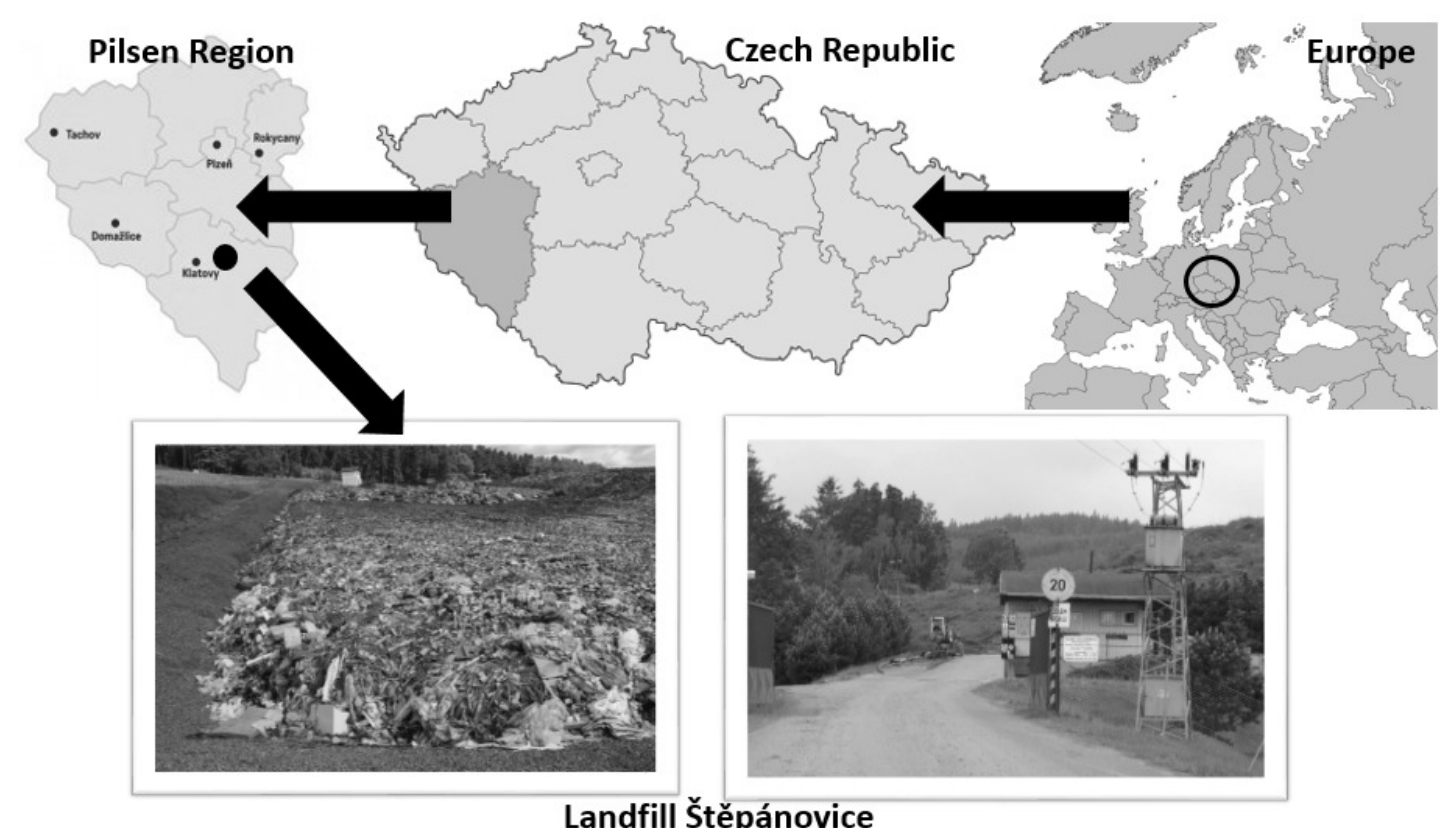

Fig. 3. Location of Štěpánovice landfill

The landfill is located in the northern part of the wide-open valley. From the north and south, the landfill is surrounded by a vegetation area dominated by common pines. The hilly landscape, both in the western and eastern part of the lowland, is used for agriculture. The climate of this area is inland, with an average annual rainfall of over $582 \mathrm{~mm}$ and an average annual temperature of $8.0^{\circ} \mathrm{C}\left(\max .32 .3^{\circ} \mathrm{C}\right.$ and $\left.\min .-4.5^{\circ} \mathrm{C}\right)$.

So far, 323,913 $t$ of waste have been deposited at the Štěpánovice landfill in 1996-2011, 67,141 t of which were biodegradable rainfall. Gas management at the landfill is carried out by vertical and horizontal systems. The vertical system (wells) is created by special boreholes at the bottom of the landfill. As the waste mass increases, the wells are constantly lengthened due to sliding arms with a diameter of 600-1,000 mm (Fig. 4).

In the middle of each well there is a perforated pipe, which is protected by a fraction of aggregate. The wells are insulated to prevent the release of landfill gas into the atmosphere. The shield prevents air from entering the landfill and mixing it with the landfill gas. Horizontal gas management (intake) is created by perforated pipelines placed in horizontal discharge layers with a minimum slope of $2 \%$ (Adamcová, Vaverková \& Břoušková, 2016).
Landfill reclamation has been designed in accordance with regulations and standards that are in force in the Czech Republic (ČSN 83 8035). During the storage of waste in the first stage of operation of the Štěpánovice landfill, earth embankments with maximum height of $2 \mathrm{~m}$ were built around the landfill. Thanks to this treatment, the transfer of light fractions and waste to the surrounding areas was eliminated. This technological process caused the final shaping of the body with assumed maximum slopes from $1: 3$ to $1: 4$. The final construction of the landfill body was created on the basis of design documentation, by connecting the landfill ditches and vegetated earth embankments. The excess material that was not used was deposited in the second stage of the landfill. The purpose of the work was: (1) to preserve the existing landfill area; (2) reconstruction of the landfill surface to ensure surface water runoff; (3) one balanced earthmoving - excavation sites in the vegetated embankments of the existing landfill; (4) shaping slopes on slopes to ensure a smooth fit of other structural layers as part of reclamation, achieving a maximum slope of $1: 2.75$, enabling the introduction of vegetation as part of biological reclamation.

Part of technical reclamation is the last, 0.5-meter thick, waste layer, which consisted of: sand, plaster, 


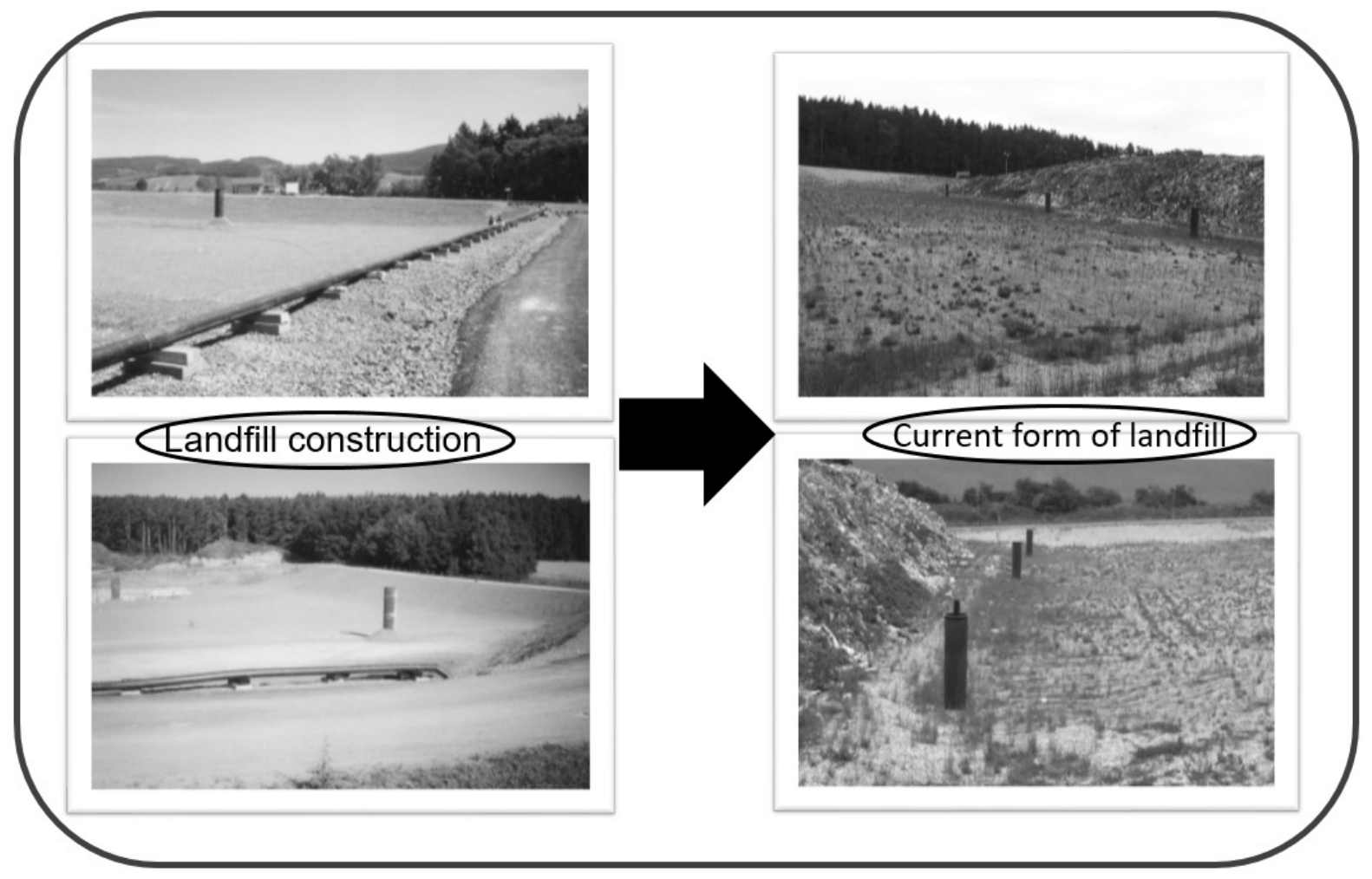

Fig. 4. The vertical system (gas management) - Štěpánovice landfill

small construction waste. As a result, the terrain must be flat, free of all protruding and sharp objects, so as not to damage other structural layers. A drainage pipeline system was made, which was laid in gravel backfill (filter) at a depth of about $0.4 \mathrm{~m}$. Drainage was covered with gravel to ground level. Protective geotextile was laid next, which serves as mechanical protection of the insulating film (geomembrane) against damage. It was connected by welding (Fig. 5). Then an insulating layer was made. HDPE geomembrane was used, which was laid parallel to the ground level (slope). On the upper surface (crown of the landfill) a smooth geomembrane was used, while on the slopes - rough (textured) (Adamcová \& Vaverková, 2014).

As part of drainage of the reclaimed part of the landfill, elements protecting against inflow of external waters were used until the construction of the headquarters was completed. At a properly reclaimed landfill, rainwater will no longer stagnate. There must be a gravity water flow from the reclaimed landfill surface. Therefore, a surface slope greater than $3 \%$ should be created.
The last stage of technical reclamation is placing a layer of soil (humus) on the entire surface of the landfill, which allows the initiation of the process of vegetation as part of biological reclamation. It has to be made sure that the coarse fraction is placed in the bottom part, as it is not suitable for the top layer due to its low retention capacity.

Conducting biological reclamation treatments in technically reclaimed areas is a process that transforms these areas. The purpose of biological reclamation is to create conditions for the growth of vegetation. In order to integrate the reclaimed landfill into the surrounding landscape, it is necessary to choose the right direction of biological reclamation and create appropriate habitat conditions for plants. The economic aspects of reclamation and the importance of the place for the environment and the local community should also be taken into account. To sum up, it can be stated that the waste landfill cover is formed by a compensatory waste layer, compacted clay $(20 \mathrm{~cm})$, bentonite and a vegetative soil layer 

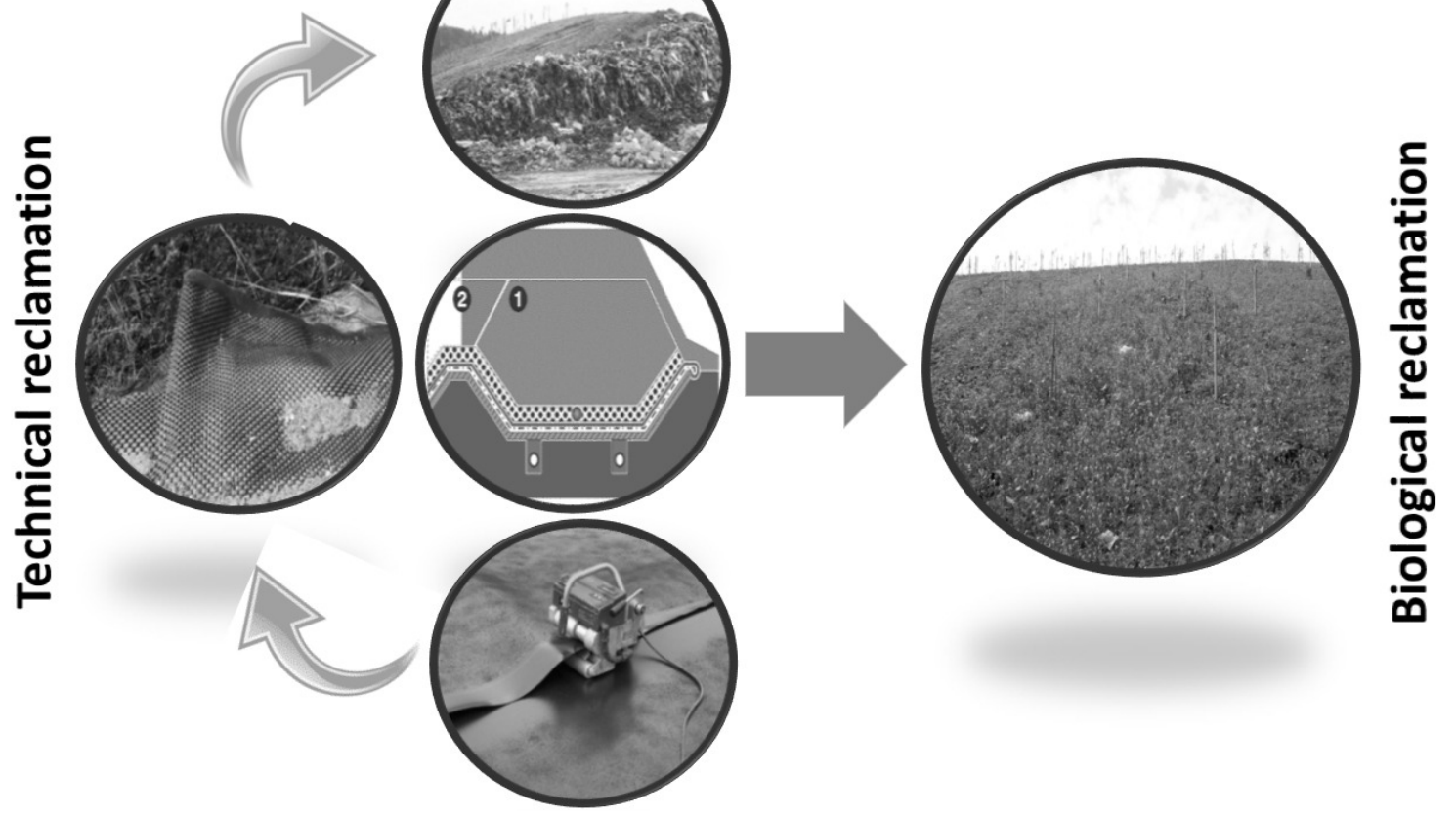

Fig. 5. Technical reclamation

- humus (up to $100 \mathrm{~cm}$ ). The next stage, i.e. grass covering or afforestation with local vegetation, occurs after the next part of the landfill has been closed (Vaverková \& Adamcová, 2018).

\section{RESULTS AND DISCUSSION}

Thanks to the use of solutions from a number of disciplines, i.e. hydrogeology, environmental protection, geotechnics, sanitary engineering, construction and area management, effective land reclamation can be conducted. Hydrogeological conditions, history and characteristics of the facilities, the impact of landfills on the environment determine the form and direction of reclamation of a given facility. The protection of the water and soil environment against the movement of pollutants in the landfill area is often important due to the long-term negative impact of the facility on the natural environment, which should be eliminated or definitely limited. Attention should also be paid to the impact of leachate on the durability of the materials from which the elements of landfill protection are made.
The most important tasks of landfill reclamation are to minimize or eliminate the landfill's impact on the water and soil environment, and emissions to the atmosphere (Vaverková, 2019), which can be achieved by using vertical insulation screens (for landfills that do not have an insulated base), tight covering of the landfill, and introducing vegetation to the surface (Koda \& Osiński, 2017). Another goal of the site's reclamation is to adapt it to the intended purpose of the area, i.e. to give usable functions in relation to the guidelines contained in the local area development plan.

Covering the surface of the landfill is the most common and basic treatment used during the reclamation of the facility, which reduces the impact of pollution on the environment (Lombardi, Carnevale \& Corti, 2006; Weng, Fujiwara, Houng, Sun, Li \& KuWeng, 2015). Protection against emissions into the atmosphere and limiting the amount of leachate formed is the main purpose of the cover (Karak, Bhagat \& Bhattacharyya, 2012; Koda et al., 2013). When applying this treatment, the use of a mineral insulation is the best option. However, it should be adapted to the conditions of soil selection, as well as the rules of embedding the 
material and testing the quality of works, so as not to cause failure of the structural elements (Koda, Grzyb, Osiński \& Vaverková, 2019).

When comparing the methods of closing and reclamation of Słabomierz-Krzyżówka and Štěpánovice landfills, one can notice similarities and differences. They begin with the complete procedure regarding the closing of the landfill, i.e. the procedures used to prepare and conduct the work on landfill reclamation, which is carried out in the following order: (1) preparatory process; (2) technical reclamation; (3) biological reclamation and (4) post-reclamation land management. The whole process, both in Poland and the Czech Republic, is carried out similarly and goes through all the above-mentioned stages.

The reclamation treatment applied at the Słabomierz-Krzyżówka and Štěpánovice landfills was the surface covering, which consisted of similar layers, but some differences can be observed. In Poland it is: compensation layer, insulation layer, drainage layer, reclamation layer and protective layer, while in the CR it is: levelling layer, degassing layer, geotextile, insulation layer (HDPE geomembrane), geotextile, drainage layer and cultural layers of soil. The main difference is the use of geomembrane (HDPE) in the Czech Republic in a complex covering system that is not required in Poland. An additional element used when closing the Słabomierz-Krzyżówka landfill was the construction of a bentonite anti-filtration barrier around the landfill, which resulted from the need to protect groundwater due to the lack of insulation of the landfill base when establishing it. There are also slight differences in the leachate collection and management systems and the degassing method of the analysed landfills.

When starting work on shaping and securing landfills, the first element is the construction of earth embankments around the landfill to protect against the movement of small fractions or waste. Both in Poland and the Czech Republic, this solution was used on selected objects. In addition, they were built to the same height of $2.0 \mathrm{~m}$. The table shows comparative examples for closed landfills in Poland and the Czech Republic.

Table. Comparison of closing and reclamation of landfills in two countries

\begin{tabular}{|c|c|c|}
\hline \multirow{2}{*}{ Comparative examples } & \multicolumn{2}{|c|}{ Closing and reclamation of a landfill in a selected country } \\
\hline & Poland & the Czech Republic \\
\hline $\begin{array}{l}\text { Landfill security } \\
\text { (preparatory works) }\end{array}$ & $\begin{array}{l}\text { 2.0-meter high earth embankments around } \\
\text { the site }\end{array}$ & $\begin{array}{l}\text { 2.0-meter high earth embankments around } \\
\text { the site }\end{array}$ \\
\hline $\begin{array}{l}\text { Procedures used to } \\
\text { prepare, and conduct } \\
\text { works at landfill } \\
\text { reclamation }\end{array}$ & $\begin{array}{l}\text { - preparation process } \\
\text { - technical reclamation } \\
\text { - biological reclamation } \\
\text { - post-reclamation area management }\end{array}$ & $\begin{array}{l}\text { - technical reclamation } \\
\text { - biological reclamation } \\
\text { - ongoing process during above mentioned } \\
\text { reclamation } \\
\text { - post-reclamation stage }\end{array}$ \\
\hline Landfill covering layers & $\begin{array}{l}\text { - compensation layer } \\
\text { - insulation layer } \\
\text { - drainage layer } \\
\text { - reclamation layer } \\
\text { - protective layer }\end{array}$ & $\begin{array}{l}\text { - levelling layer } \\
\text { - degasing layer } \\
\text { - geomembrane } \\
\text { - insulation layer } \\
\text { - geotextile } \\
\text { - drainage layer } \\
\text { - cultural layers of soil }\end{array}$ \\
\hline Drainage layer & made of $0.15-0.20$-meter thick medium sand & made of 0.5-meter thick gravel \\
\hline Insulation layer & $\begin{array}{l}\text { should be made of mineral material of special } \\
\text { properties or with an addition of a substance } \\
\text { improving insulating properties }\end{array}$ & $\begin{array}{l}\text { should be made foil, bentonite mattress or } \\
\text { another layer with similar insulating properties }\end{array}$ \\
\hline Landfill monitoring & crucial and in use & crucial and in use \\
\hline
\end{tabular}




\section{CONCLUSIONS}

The final effect after complete closing of the landfill is covering the surface with vegetation and land development according to the previously assumed concept and purpose of the area. When performing these activities, economic conditions and fitting into the landscape surrounding the landfill should be taken into account.

Incorrectly functioning, most often old, landfills can have a very negative impact on the environment. Soils and water tanks in adjacent areas may be contaminated. The air is also exposed to pollution. After the end of its operating period, the landfill may still have an adverse effect on all natural components. Therefore, closing landfills is a very important process in the aspect of environmental protection, which is of technological, legal and organizational nature. Reclamation of a landfill should be conducted in accordance with clearly presented time schedules that result from an administrative decision in a manner that protects the landfill against its adverse impact on the environment. Reclamation processes are aimed at enabling the best possible connection of the landfill area with the surrounding area, as well as ensuring the implementation of monitoring that shows the impact of the landfill on the environment, which may result in the need for further remedial actions. However, as the most important and main goal of the course of closing process and reclamation of a given facility, it is recognized to reduce threats that have an impact on the environment and to ensure that the required level of the landfill is not disturbed. It means maintaining good quality of the facility and technical and environmental standards. These goals were achieved in both analysed landfills despite some differences in the closing process of both landfills.

\section{Acknowledgements}

The author thanks the companies ARPAGEO and Geotechnika i Środowisko and the management of Štěpánovice landfill for providing data and documentation.

\section{REFERENCES}

Abad, V., Avila, R., Vicent, T. \& Font, X. (2019). Promoting circular economy in the surroundings of an organic frac- tion of municipal solid waste anaerobic digestion treatment plant: Biogas production impact and economic factors. Bioresource Technology, 283, 10-17.

Adamcová, D. \& Vaverková, M. (2014). Evaluation of landfill pollution with special emphasis on heavy metals. Journal of Ecological Engineering, 15 (2), 1-6.

Adamcová, D., Vaverková, M. D. \& Břoušková, E. (2016). Emission assessment at the Štěpánovice municipal solid waste landfill focusing on $\mathrm{CH}_{4}$ emissions. Journal of Ecological Engineering, 17 (3), 9-17.

Burlakovs, J., Kriipsalu, M., Klavins, M., Bhatnagar, A., Vincevica-Gaile, Y., Stenis, J., Jani, Z., Mykhaylenko, V., Denafas, G., Turkadze, T., Hogland, M., Rudovica, V., Kaczala, F., Rosendal, R. M. \& Hogland, W. (2017). Paradigms on landfill mining: From dump site scavenging to ecosystem services revitalization. Resources, Conservation \& Recycling, 123, 73-84.

Council Directive 1999/31/EC of April 261999 on the landfill of waste. OJ L 182/1 of 16.7.1999.

ČSN 83 8035:1996. Skládkování odpadů - uzavíraní a rekultivace skládek [Waste landfilling - Landfilling and reclamation].

Decision No 1386/2013/EU of the European Parliament and of the Council of 20 November 2013 on a General Union Environment Action Programme to 2020 'Living well, within the limits of our planet'. OJ L 354/171 of 28.12.2013.

Ercolano, S., Gaeta, G. L. L., Ghinoi, S. \& Silvestri, F. (2018). Kuznets curve in municipal solid waste production: An empirical analysis based on municipal-level panel data from the Lombardy region (Italy). Ecological Indicators, 93, 397-403.

Eurostat (2016). Municipal waste by waste management operations (env_wasmun).

Górecka, A. \& Koda, E. (2010). Analysis of possibilities to reduce the risks of groundwater pollution resulting from operating of the modernized sanitary landfill. Scientific Review Engineering and Environmental Sciences, 3 (49), 48-62.

Ishimura, Y. \& Takeuchi, K. (2019). The spatial concentration of waste landfill sites in Japan. Resource and Energy Economics, 58, 101-121.

Jovanov, D., Vujić, B. \& Vujić, G. (2018). Optimization of the monitoring of landfill gas and leachate in closed methanogenic landfills. Journal of Environmental Management, 216, 32-40.

Karak, T., Bhagat, R. M. \& Bhattacharyya, P. (2012). Municipal solid waste generation, composition, and management: the world scenario. Critical Reviews in Environmental Science and Technology, 42 (15), 1509-1630. 
Koda, E. (2009). Geoenvironmental aspects of reclamation of waste landfills. Inżynieria Morska i Geotechnika, 30 (3), 134-151.

Koda, E., Grzyb, M., Osiński, P. \& Vaverková, M. D. (2019). Analysis of failure in landfill construction systems. MATEC Web of Conferences, 284, 03002, ICSF 2019, 10.1051/matecconf/201928403002

Koda, E. \& Osinski, P. (2017). Bentonite Cut Off Walls: Solution for Landfill Remedial Works. Environmental Geotechnics, 4 (4), 223-232, https://doi.org/10.1680/ jenge.14.00022

Koda, E., Pachuta, K. \& Osiński, P. (2013). Potential of plants application in the initial stage of landfill reclamation process. Polish Journal of Environmental Studies, 22 (6), 1731-1739.

Laner, D., Crest, M., Scharff, H., Morris, J. W. F. \& Barlaz, M. A. (2012). A review of approaches for the long-term management of municipal solid waste landfills. Waste Management, 32 (3), 498-512.

Lombardi, L., Carnevale, E. \& Corti, A. (2006). Greenhouse effect reduction and energy recovery from waste landfill. Energy, 31 (15), 3208-3219.

Manczarski, P. \& Lewicki, R. (2012). Wytyczne dotyczace zamykania i rekultywacji składowisk odpadów komunalnych. Narodowy Fundusz Ochrony Środowiska i Gospodarki Wodnej, Warszawa.

Peri, G., Ferrante, P., La Gennusa, M., Pianello, C. \& Rizzo, G. (2019). Greening MSW management systems by saving footprint: The contribution of the waste transportation. Journal of Environmental Management, 219, 74-83.

Pietzsch, N., Ribeiro, J. D. L. \& Medeiros, J. F. (2017). Benefits, challenges and critical factors of success for zero waste: a systematic literature review. Waste Management, 67, 324-353.

Rozporządzenie Ministra Środowiska z dnia 30 kwietnia 2013 r. w sprawie składowisk odpadów. Dz.U. 2013, poz. 523 [Regulation of the Minister of the Environment of 30 April 2013 on landfills. Journal of Laws 2013, item 523].

Vaverková, M. D. \& Adamcová, D. (2018). Case Study of Landfill Reclamation at Czech Landfill Site. Environmental Engineering and Management Journal, 17 (3), 641-648.

Vaverková, M. D. (2019). Landfill Impacts on the Environment - Review. Geosciences, 9 (10), 431, https://doi. org/10.3390/geosciences 9100431

Weng, Y-C., Fujiwara, T., Houng, H. J., Sun, C-H., Li, W-Y. \& Kuo, Y. W. (2015). Management of landfill reclamation with regard to biodiversity preservation, global warming mitigation and landfill mining: experiences from the Asia-Pacific region. Journal of Cleaner Production, 104, 364-373.

Ziyang, L., Luochun, W., Nanwen, Y. \& Youcai, Z. (2015). Martial recycling from renewable landfill and associated risks: A review. Chemosphere, 131, 91-103.

\section{PORÓWNANIE TECHNICZNYCH SPOSOBÓW ZABEZPIECZENIA ZAMYKANYCH SKŁADOWISK ODPADÓW W REPUBLICE CZESKIEJ I POLSCE}

\section{STRESZCZENIE}

Składowiska i/lub otwarte wysypiska odpadów od lat były powszechnie stosowaną praktyką unieszkodliwiania odpadów komunalnych na całym świecie. Składowanie jest jedną z najstarszych i wciąż najczęściej stosowanych metod usuwania odpadów. Wynika to z niskich kosztów eksploatacyjnych w porównaniu $\mathrm{z}$ innymi metodami unieszkodliwiania odpadów. Celem niniejszej pracy było porównanie metod zabezpieczania składowisk odpadów w Republice Czeskiej i Polsce. W Polsce zostało przeanalizowane składowisko odpadów Słabomierz-Krzyżówka, w Republice Czeskiej składowisko Štěpánovice. Rekultywacja składowisk odpadów jest bardzo ważnym procesem z punktu widzenia ochrony środowiska przyrodniczego i ma charakter technologiczny, prawny i organizacyjny. Rekultywacja składowiska powinna odbywać się zgodnie $\mathrm{z}$ jasno przedstawionym harmonogramem wynikającym $\mathrm{z}$ decyzji administracyjnych w sposób chroniący składowisko przyrodnicze przed negatywnymi wpływami. Cele te zostały osiągnięte na obu analizowanych składowiskach, pomimo pewnych różnic w procesie rekultywacji obu składowisk.

Słowa kluczowe: składowisko, rekultywacja techniczna, rekultywacja biologiczna, zabezpieczenie 